This item was submitted to Loughborough's Research Repository by the author.

Items in Figshare are protected by copyright, with all rights reserved, unless otherwise indicated.

\title{
Information warfare and new organizational landscapes: an inquiry into the ExxonMobil-Greenpeace dispute over climate change
}

PLEASE CITE THE PUBLISHED VERSION

http://dx.doi.org/10.1080/0969160X.2014.885195

\section{PUBLISHER}

Taylor \& Francis @ Petros Vourvachis

\section{VERSION}

VoR (Version of Record)

\section{PUBLISHER STATEMENT}

This work is made available according to the conditions of the Creative Commons Attribution-NonCommercialNoDerivatives 4.0 International (CC BY-NC-ND 4.0) licence. Full details of this licence are available at: https://creativecommons.org/licenses/by-nc-nd/4.0/

\section{LICENCE}

CC BY-NC-ND 4.0

\section{REPOSITORY RECORD}

Vourvachis, Petros. 2019. "Information Warfare and New Organizational Landscapes: An Inquiry into the Exxonmobil-greenpeace Dispute over Climate Change". figshare. https://hdl.handle.net/2134/19632. 


\title{
Information Warfare and New Organizational Landscapes: An Inquiry into the ExxonMobil - Greenpeace Dispute over Climate Change
}

\author{
B. Mackay and I. Munro
}

Organization Studies 2012, 33 (11), pp. 1507-1536

This is a very interesting case study on information warfare in action. It focuses on exploring the information tactics ExxonMobil and Greenpeace deploy against each other, in an attempt to alter the public's perception over the issue of climate change. The discussion is framed within a neoGramscian perspective drawing on social movement organisational theory. In the authors' words, "[a]n information warfare perspective allows for processes of negotiation and compromise, but explores the possibility that underlying such negotiations we can find deliberate, directed and destabilizing tactical attacks upon the information resources of the different parties involved" ( $p$. 1516). To investigate these arguments the authors considered a range of sources, including corporate press releases, media reports, public correspondence, leaked memos and internet websites. This enabled them to build a timeline and describe interventions by the two organisations for the period 1998-2010.

This paper seems to complement the one by Brennan et al. (2013), which analyses a conflict between Greenpeace and firms in the sportswear/fashion industry over water pollution in China. By analysing press releases over a three-month window, Brennan et al. explore a short-term conflict involving Greenpeace, whereas Mackay and Munro take a wider perspective, looking at how communication tactics evolve over a number of years. Despite using different theories (Brennan et al. employ a dialogical frame based on legitimacy theory and on Benoit's theory of image restoration), both studies find evidence that communication is a function of the power relations between firms and specific stakeholders and highlight the role of strategies, such as silence, denial, dispute and conciliation in organisational interaction. This does raise questions over the utility of the information warfare arguments in social and environmental accounting research (although the reported evidence from both studies would suggest that the term warfare seems to be more suitable than dialogism to describe Greenpeace's state of affairs with the examined organisations!). Indeed, Mackay and Munro's lack of consideration of the relevant literature is often revealed through a number of unsubstantiated claims made throughout the paper (regarding e.g. the literature's "insufficient attention to theorizing the specific nature of the informational strategies and tactics that have been used to legitimize and delegitimize the framing of the climate change debate" [p. 1508], or the lack of research on how "organizations have sought to manipulate their business environment" by using "particular semiotic strategies" [p. 1531]).

Overall, the paper does offer a very thorough review of the literature on information warfare and a fascinating account of the ExxonMobil - Greenpeace relationship, which could also be very useful teaching material. It particularly showcases the use of internet resources over the longer term in shaping public perceptions but also more intensively highlights the related potential risks and opportunities for social movement. I would certainly recommend reading it.

\section{Reference}

Brennan, N. M., Merkl-Davies, D. M. and Beelitz, A. (2013), "Dialogism in corporate social responsibility communications: conceptualising verbal interaction between organisations and their audiences", Journal of Business Ethics, 115 (4), pp. 665-679. 